\title{
A Phone of One's Own: Woolf, TikTok and the Aesthetic Evolution of Bisexuality
}

\author{
Christopher James Wells
}

PhD Student, School of English, University of Sheffield, cjwells1@sheffield.ac.uk

\begin{abstract}
Whereas bisexuality, as it existed in modernity, has been described as a 'floating signifier $^{1}{ }^{1}$, one that was problematically conflated with gender and intersex bodies, the articulation of bisexuality is now experiencing a discursive resurgence in spaces and platforms online. Through a deliberately disparate comparison between Virginia Woolf's modernist writing and the discussions of bisexuality on the video-sharing social networking service TikTok, this essay presents a reflective reassessment of how far bisexual representation in the popular imagination has progressed and by extension, evaluate extant limitations. To realize these ambitions, I compare the reception of sexology (the new science of sexuality) in 'high' modernist literature with a post-modern demographic whose bisexuality is articulated in the 2020s online via TikTok's towards what I would demarcate as a post-queer theory user base. This essay is not intended as an overview of the advancements made in psychoanalytic institutions about bisexuality nor does it set out to comment on the refinement of bisexuality's aestheticization through time. Instead, it uses these two temporally specific moments in the cultural zeitgeist to compare and contrast how differently two different demographics articulate bisexuality, both as a written mode in modernism and as a visual apparatus online. This is less a critique of bi-erasure, but an interrogation of why and how bisexual representation, as an aestheticized subjectivity that compromises romantic, spiritual, and erotic desires for bodies of all genders, continues to be problematically restrictive.
\end{abstract}

Keywords: keyword 1; Bisexuality 2; Woolf 3; Modernism 4; Sexology 5; TikTok

\section{Introduction:}

'We shall not really succeed in discarding the straitjacket of our cultural beliefs about sexual choice if we fail to come to terms with the well-documented, normal human capacity to love members of both sexes'2. -Margaret Mead, Bisexuality: What's It All About? 1975

This article offers a comparison of two radically disparate temporal moments in queer history: the ideological and aesthetic intentions behind modernist bisexual writer Virginia Woolf's work; and the strategies deployed by bisexual users on the social media platform Tik Tok. The comparison is done to compare the 'sex-saturated age ${ }^{3}$ of modernity with our contemporary landscape that I would term both hyper/techno-modern and as 'post-queer theory', wherein ideas of gender as social constructions and non-binary sexualities (including bisexuality) are widely disseminated and articulated by Tik Tok users- typically between 18 and 25 years old- with increasingly sharpness, sensitivity, astuteness, and ease. I do this to assess the similarities, differences, and the limitations still

\footnotetext{
1 Brenda S. Helt. 'Passionate Debates on "Odious Subjects": Bisexuality and Woolf's Opposition to Theories of Androgyny and Sexual Identity', Twentieth Century Literature (56) 2, (2010), 131-67. 〈http://dx.doi.org/www.jstor.org/stable/41062468>

2 Margaret Mead, Coming of Age in Samoa (1928; London: Pelican Books, 1975); Margaret Mead, "Bisexuality: What's it All About?," Redbook, January 1975, 29-31.

${ }^{3}$ Deborah Moddelmog, 'Modernism and Sexology', Literature Compass 11, no.4 (2014) pp. 267-278. 〈https://doi.org/10.1111/lic3.12140> pp. 267-278.
} 
faced in (re)presenting bisexuality, or to use a modernist turn-of-phrase, of 'writing the self $^{\prime}$. I have also chosen this comparison to explore the differences in written and webnormative visual representations of bisexuality. By extension, this comparative model will examine the literary inscription of those ideas that circulated in sexual science and literary imagination of Woolf's cultural milieu compared with a composite ideology of post-queer theory and the problematic cinematic depictions of bisexuality that many bisexual scholars denote as bi-erasure and bi-invisibility within a 'landscape of compulsory monosexuality'. $^{5}$ I hope that these two very different modes of production and mechanisms of articulation (the written and the visual) can showcase how far bi representation has come as well as discern recurring concerns of bisexuals in their striving for visibility. Furthermore, this comparison between Woolf and Tiktok is made in order to identify the residual influence of sexology and modernist literature in the contemporary tools of self-labelling and self-expression of the bisexual community. In doing so, it is intended as a reflection the similarities and differences between the modernist relationship to those labels and a burgeoning 'inward turn' that conceives and facilitates, paradoxically, a 'writing of the self' that is self-consciously showcased online, as opposed to expressed in Wolfian and modernist experiments by writing a new, modern self- what Woolf described perhaps more passively as 'a shower of atoms on the mind'.

\section{Methodology}

This comparison between how bisexuality is articulated and specifically how one expresses or 'writes' their bisexual-self in both the written and image-based form will show how far we have come and assess the limits of bisexual representation. It is also an extreme comparison because Virginia Woolf's disquisition is worlds apart from the sixty seconds permitted in Tik Tok videos. This essay is not intended as a recuperative or a revisionary project to unearth or expose the significance of bisexuality within modernity or to critique bi-erasure now but instead uses two very different modes of representation to contemplate and reflect on how far bisexuality has progressed in its ability to be represented accurately and satisfactorily. It also uses this approach to identify similar concerns of those earlier writers and those users online whose apparatus for self-expression was crafted in two very different conditions of production and contexts of consumption. Essentially, this essay will examine how far as a bisexual community we have come, and how far we have to go if we are to understand how we can best articulate our experiences in a culture predicated on binary oppositions and binary codes of conduct. I want to compare these two moments in queer history, then and now, to think critically about how a bisexual internalizes and externalizes their sense of self in a 'landscape of compulsory monosexuality' where, for men, 'if you don't like girls, then you must be gay, right?' When one identifies as bisexual it is, strangely, often perceived as a choice to exist outside of essential and totalizing essences: true homosexuality or heterosexuality.

Whilst it could be said to be incongruous and inappropriate to compare apples and oranges in citing the well-known experimental elitist modern writers with a platform such as TikTok, it is an important model of comparison because the historical contexts in which these two platforms of representation have been constructed and consumed are both, for very different reasons, moments in which discussions of m-spec (the multiple gender attraction spectrum) identities were the most vocal and resonant. At the turn of the twentieth century we saw the advent of sexological discussion around the problematic notion of

4 Joseph Allen Boone, Libidinal Currents Sexuality and the Shaping of Modernism (Chicago and London: University of Chicago Press, 1998), p. 5.

${ }_{5}$ Christopher James, 'Denying complexity: The dismissal and appropriation of bisexuality in queer, lesbian, and gay theory' in Queer Studies: A Lesbian, Gay, Bisexual, and Transgender Anthology ed. by Brett Beemyn and Michelle Eliason, (New York: New York University Press, 1996), 321-335 (p.322). 
bisexuality as something that both embarrassed all of Freud's inquiries and instilled a burgeoning sense of 'uncertainty and doubt' ${ }^{6}$ in sexologist Havelock Ellis's attempt to find out the essential (monosexual) truth of sex. Similarly, the cultural references cited on TikTok by users (contemporary television, cinema, music) are framed by a post-modern audience well-versed in queer theory and in a landscape where sexualities outside of the binary of hetero/homo are visually circulated on social media and discussed online with increasingly articulate and perceptive attitudes towards bisexuality. This comparison, hopefully, will allow us to tease out commonalities between the strategies used to (and intentions behind) representing bisexuality, as well as providing us a space to consider where exactly we are with bisexual representation, who it is helping and why it is still needed.

\section{Modernity and Bisexuality}

In 1928 a 'young Indochinese emigrant living in Paris' named Pierre Do-Dinh wrote a letter to author Andre Gide encapsulating the ideological aims released by aestheticization as Do-Dinh described the writerly impulse as being 'preoccupied with the mystery of interiority, which reverberates in the anxieties and darkness of our subconscious' ${ }^{7}$ This modernist 'inward turn' to 'make it new' in poet Ezra Pound's manifesto-like declarative, was seen to be achieved by wading in the murky waters of what James Joyce famously called the 'subterranean complexities' of 'the new realism' that committed to articulating the 'modern theme [that] is the subterranean forces, those hidden tides which govern everything and run humanity counter to the apparent flood: those poisonous subtleties which envelop the soul, the ascending fumes of $\operatorname{sex}^{\prime}{ }^{8}$. This was in part to radically break down and depart from what Joyce described as 'the fixed mood of the classical style' that was now seen as an inadequate and disingenuous apparatus for representing subjective interpretations of lived experiences. Instead, the 'modern theme' of sexuality, as a 'libidinal current $^{\prime 9}$ was much better represented by a style that would facilitate and accommodate depictions of 'an endlessly changing surface, dictated by the mood and current impulse' that 'in writing, one must create' ${ }^{\prime 10}$ (Joyce, in Power, p.109). This writerly impulse to capture the realities of multiple gender attractions, as and when they naturally occur was also extolled by Woolf (1925) in Modern Fiction for writers seeking to advance the realities of sexual experience to:

'record the atoms as they fall upon the human mind in the order in which they fall, let us trace the pattern, however disconnected and incoherent in appearance, which each sight or incident scores upon the consciousness. Let us not take it for granted that life exists more fully than in what is commonly thought big than in what is commonly thought small. ${ }^{11}$

Hence, what was often described as elitist experimentation was more a realist project, as Joyce said of French writer Marcel Proust, Proust's writing 'was not experimental[...]

${ }^{6}$ Havelock Ellis 'Studies in the Psychology of Sex, vol.II: Sexual Inversion', in Sexology Uncensored The Documents of Sexual Science, ed. by Lucy Bland and Laura Doan, Cambridge: Polity Press, 1998), 52-57 (p. 53).

7 Ben Tran, 'Queer Internationalism and Modern Vietnamese Aesthetics', in The Oxford Handbook of Global Modernisms, ed. by Mark Wollaeger and Matt Eatough (Oxford: Oxford University Press, 2019), 367-384 (p.367).

8 Arthur Power, Conversations with James Joyce, (The Lilliput Press: London, 1974/99), p.64.

9 Boone, p.1.

10 Power, p.109.

11 Virginia Woolf, Modern Fiction', in The Essays of Virginia Woolf Volume 4: 1925 to 1928, ed. by Andrew McNeille (London: The Hogarth Press, 1984), pp.157-164. 
his innovations were necessary to express modern life'. ${ }^{12}$ This desire to depict psychological reality is both similar in intention, yet different in strategy with the ways in which users on social media stylistically curate and construct a spectacle of explicitly exteriorized images that are produced for consumption by other users, like the modernist tradition turned inside out. In both these timepoints, the conditions of literary production are suffused and scaffolded by a personal and political desire to disrupt and delegitimize these meta-narratives that are predicated upon an assumption of homogenous sexual identities. Purposeful refraction and a fragmentation of the 'illusion of interior coherence' ${ }^{13}$ given by the fixity of hetero- or homosexuality, two monolithic modes of monosexuality that marginalize more fluid sexual desire, illegible within binary thinking that presupposes an 'Other' ${ }^{\prime 14}$. What really subtended this writerly intention in modernity was the 'undercurrent' $^{15}$ of 'uncertainty and doubt' ${ }^{16}$ that flowed without fixity within the sexological investigation into bisexuality. What was integral to this fracturing and rupturing of a singular, unified illusory stable self was the 'ghostly other' ${ }^{17}$ of bisexuality. On a wider level, this moment in the history of sexuality would be described by sociologist Ken Plummer as a 'veritable erotopian landscape' ${ }^{18}$. Indeed, the conditions of literary production that framed writers like James Joyce and Virginia Woolf were similar to those that Plummer recognized as an ideological drive that subtended sexual discourse in the mid-nineties that he personified as an impulse asking us to: 'tell us about your sexual behaviour[...]your sexual addictions'. ${ }^{19}$ Whilst this was certainly symptomatic of modernity's inward turn that facilitated the desire to distil the essence of 'the truth' ${ }^{20}$ of sexuality as an innate instinct (rather than a momentary perversity), I argue that the modernist discourses on bisexuality (as opposed to those on normal/heterosexual and inverted/homosexual) were distinctive as a subjective equivalent of what queer theorist Michel Foucault designated as a 'heterotopia', something he describes as:

There are also, probably in every culture, in every civilization, real places-places that do exist and that are formed in the very founding of society - which are something like countersites, a kind of effectively enacted utopia in which the real sites, all the other real sites that can be found within the culture, are simultaneously represented, contested, and inverted. Places of this kind are 4 outside of all places, even though it may be possible to indicate their location in reality. Because these places are absolutely different from all the sites that they reflect and speak about, I shall call them, by way of contrast to utopias, heterotopias ${ }^{21}$.

\section{Virginia Woolf and Bloomsbury's 'plural affections'}

Different though the sexes are, they intermix. In every human being a vacillation from one sex to the other takes place ... . Of the complications and confusions which thus result every one has had experience; but here we leave the general question and note only the odd effect it had in the particular case of Orlando herself ${ }^{22}$.

12 Power, p.91.

13 Judith Butler, Bodies That Matter: On the Discursive Limits of Sex (London: Routledge, 1993), p.56.

14 Edward Said, Orientalism (London: Routledge and Kegan Paul, 1978), p.1.

15 Power, p,32.

16 Ellis, 1915, p.433.

17 Steven Angelides, A History of Bisexuality (London: University of Chicago Press, 2001).

18 Ken Plummer, Telling Sexual Stories . Power, Change and Social Worlds. (London: Routledge, 1995), p.4

19 Ibid, p.95

20 Ellis, 1897, p.3.

21 Michel Foucault, 'Of Other Spaces: Utopias and Heterotopias' in Architecture /Mouvement/ Continuité October, 1984; (“Des Espace Autres," March 1967 Translated from the French by Jay Miskowiec) https://web.mit.edu/allanmc/www/foucault1.pdf

22 Virginia Woolf, Orlando, (London: Penguin, (1928) 2005), p.129. 
Virginia Woolf was a writer who was bisexual and part of what we now refer to as the Bloomsbury group, a group of middle-class writers and artists including Woolf and her female lover Vita Sackville-West, who was also married to a man. Similarly, painter Duncan Grant had sexual relations with working-class Jamaican-born migrant Patrick Nelson. Sackville-West's husband, writer and lecturer Harold Nicholson also had 'such plural affections' ${ }^{23}$ and would regularly liaise with men. Within this group sex was a topic keenly discussed after one pivotal moment. In Old Bloomsbury, Virginia Woolf tells of a frank and open discussion of sexual matters that ensued in a drawing-room one day in 1906, after Lytton Stratchey, pointing to Vanessa's dress and without fear of consequence made a strikingly transparent observation of a semen stain. As Woolf narrated:

'Semen' he said 'Can one really say it? I thought and we burst out laughing. With that one word all barriers of reticence and reserve went down ...Sex permeated our conversation. The word bugger was never far from our lips. We discussed copulation with the same excitement and openness that we had discussed the nature of $\operatorname{good}^{24}$

In a not too dissimilar context, contemporary users of TikTok, typically between 16 and 25, have formed their opinions and perceptions of sexuality in post-queer theory landscape where the discussion of sex, sexuality and/or asexuality are discussed openly, from sex education in primary school now to university courses that house modules on Gender and Sexuality. Queer theory when it arrived, both enabled and facilitated the possibility to deconstruct the homogeneity of all identities, such as Judith Butler's description of the 'illusion of coherence' ${ }^{25}$ between external gender expression, anatomy, sexual desire, and gender/sexual identity. The dissemination of 'queer' strategies of the de/reconstruction of sexual identities has also thrown into question the binary logic underpinning oppositional taxonomies where definitions are predicated on their absent 'other', their counterpart that is not in attendance e.g. sun/moon, light/dark, straight/gay, 'active/passive' ${ }^{26}$, as Helen Cixous has outlined in their reflection of the oppressive resonances of binary thought in cultural imaginings of gender and sexuality as identities in and of themselves.

My comparison here between Woolf and TikTok then rests on the agreement with Patricia Cramer that Woolf's writing demonstrates a 'queering' of sexual 'regimes of the normal $^{\prime 27}$. Under this approach, I would refute the notion that such queer readings of Wolfian poetics of the self are 'anachronistic impositions ${ }^{28}$. Simply because Woolf did not have the language of queer theory afforded to TikTok users does not mean that she did not have the same motives as queer theorists and contemporary bisexuals in 2021. Whilst I concur that sexology was not the sole catalyst that incited the birth of 'the homosexual' as a 'species' ${ }^{29}$ in Michel Foucault's often-cited History of Sexuality, I do contend that it is overly reductive to examine Woolf's preferred terms 'Sapphic' and 'lesbian' as an indication that she was 'lesbian' in a contemporary sense of the word as an indicator of exclusively same-sex desire in women. It is reductive because it does not pay enough credence to the modernist conditions of Woolf's writerly compositions that were not permeated by

\footnotetext{
23 Marjorie Garber, Vice Versa and the Erotics of Everyday Life, (London: Pocket Books, 1994), p.322.

24 Virginia Woolf, 'Old Bloombsury', in Moments of Being ed. Jeane Schullkind $2^{\text {nd }}$ ed. (San Diego: Harcourt, 1985 ), p.43.
}

25 Judith Butler, Gender Trouble: Feminism and the Subversion of Identity (London: Routledge, 1990), p.32.

${ }_{26}$ Helene Cixous, 'Sorties: Out and Out: Attacks/Ways Out/Forays' in, The Newly Born Woman ed. By Helene Cixous and Catherine C1ement (London: Routledge, 1986), p.213.

27 Cramer, P. (2010). 'Virginia Woolf and Sexuality'. In The Cambridge Companion to Virginia Woolf ed.by Susan Sellers , (Cambridge: Cambridge University Press, 2010), pp. 180-196 (p.183).

28 Ibid.,p.184.

29 Michel Foucault, A History of Sexuality, (New York: Pantheon Books, 1978), p.43. 
terms of queer theory. However, that does not preclude the possibility that enriching readings and veritably new perspectives (such as how bisexuality manifests in Woolf's fiction) can be uncovered when analyzing Woolf's work under the lenses that frame those users on TikTok, after queer theory such as Judith Butler's many assertions of the 'instability' of ontological gender (as opposed to gendered expression as an intrinsically performative act) as well as the 'fluidity and disruption' of non-monosexual identities and their attendant 'indeterminacy' ${ }^{30}$ and 'incoherences' ${ }^{31}$ as modes of subjectivity and sexuality that problematize Ellis' drive to emancipate homosexuality from legal sanctions by 'ascertaining of the facts of what is normal and abnormal from the point of view of physiology and of psychology $\mathbf{y}^{\mathbf{3 2}}$

\section{A Phone of One's Own}

Whilst there have been entire schools of thought invested in the study of Virginia Woolf's bisexuality (with an emphasis on her sexual and emotional intimacies with VitaSackville West) as well as much work done on the representative limits of bisexuality in cinema, there is little to no research on how the aesthetics of bisexuality are disseminated online, precisely by those demographics that consume such cinematic depictions. The only article that I have come across is one in which Brandon Rogers examines how images of the male bisexual body are constructed and consumed online, and the mononormative hashtags (\#gayguy, for example) that they are subsumed within. In Rogers' \#Biguys and \#Biboys: The Discursive Production of Bisexual Men through Instagram's Homonormative Visual Culture, Brandon noted that

'On Instagram, photos tagged in reference to bisexual men were frequently linked to gay culture through the use of hashtags. Over $70 \%$ of sampled images included at least one hashtag like \#gay, \#instagay, or \#gayboy that evoked gay culture. This overwhelming overlap between hashtags suggests a strong alignment between imagined audiences and visual identities. On the one hand, this evocation of both cultures frames gay men and bisexual men as interested in the same thing: men who are sexually interested in men. On the other hand, the use of both hashtags threatens to consolidate gay and bisexual men into one shared identity category ${ }^{33}$.

Both Woolf's writing and bisexual Tik Tok videos were/are 'vehicles for disseminating ideas about sex' ${ }^{\prime 34}$ and are epistemological 'sites of revision' ${ }^{35}$ rather than as mediums of monolithic importation; that is, Woolf's work is not a linear injection or extension of sexological articulations of bisexuality nor are the users on Tik Tok simply amplifying the ideologies espoused in bisexuality as it is represented in television and cinema. I consider both bisexual readers of Woolf's fiction and the users on Tik Tok as a demographic defined by displacement and dislocation within mononormative cultures that queer theorist Christopher James calls a 'landscape of compulsory monosexuality' undergirded by what queer theorist Eve Sedgwick diagnosed as a 'chronic, now endemic crisis of hetero- and

30 Cramer, 2003, p,3.

31 Ibid., p.23.

32 Ibid., p.211.

33 Brandon Rogers, ‘\#Biguys and \#Biboys: The Discursive Production of Bisexual Men through Instagram's Homonormative Visual Culture', Journal of Bisexuality, (20) 4 http://dx.doi.org/10.1080/15299716.2020.1823298 p.18.

34 Deborah Moddlemog, 'Modernism and Sexology', Literature Compass, $11 \quad$ (4), (2014), 267-278, https://onlinelibrary.wiley.com/doi/abs/10.1111/lic3.12140p. (p.267).

35 Ibid.,p.268. 
homosexual definition' ${ }^{36}$ in Western cultures. Additionally, as Brenda Helt rightly attests, 'most of Woolf s characters are ordinary' ${ }^{37}$ and are deliberately eschewed from systematic classification within sexological taxonomies or 'rare types ${ }^{38}$, , the most-discussed 'types' ${ }^{39}$ being the intermediate sex, the third sex, the invert, the mannish lesbian and the ostensibly ingenious androgynous mind of the artist. Similarly, in 2021 the 'vehicle' of social media, the platform Tik Tok forces us to consider those 'ordinary minds' that articulate their bisexuality visually and with a set of apparatuses we now call postmodernself-reflexive referencing, deliberate pastiche, the assumption of irony, sampling, the recreation of well-worn cliches, the assumption of a sceptical and hyper-interpretive listener who receives the utterance of popular maxims, the apparatus as spectacle etc. that characterize what I might term techno-modernity. Tik Tok is the exhibition and the curation of reactions or that is, of thinking out loud, what a modernist would describe as an interior monologue, a stream of consciousness or free indirect discourse- when a character's subjectivity affects the words used to describe a scene e.g. The Uncle Charles principle in Joyce whereby Uncle Charles 'repaired to the outhouse' or Lily, the caretaker's daughter, was literally run off her feet in Joyce's 1914 short story The Dead. This knowing irony is perhaps best encapsulated by a Youtube collection of Bisexual Tik Tok's that is, with deliberate irony designed to tease out a very real, systemic iniquities propagated against bisexuals, uploaded by 'ruecloud' January 2021 entitled Bisexual TikToks, for when you don't exist, currently at three-hundred and twenty three thousand views,

\section{Mononormative Interpretations in monosexual spaces}

Being read mononormatively such as in Mrs Dalloway at the end when they are both married to men it renders them hermetically sealed from lesbian desire (obviously Woolf doesn't think this but the scene showcases the social inscriptions and strictures that align the characters as married and fixed/settled). Olivia Wood says that 'Clarissa and Sally have "left" each other at Bruton by getting married, yet that does not erase their affection for each other ${ }^{\prime 0}$. This scene foregrounds how mononormative readings of Mrs Dalloway inhibits, proscribes, and prohibits what Olivia Wood very astutely calls 'non-binary sexual inclinations' those that need to be made explicit if they are to be legitimized in social settings. The party scene in Mrs Dalloway captures the frustrations of not being visible as a bisexual in a social setting where one is seen in a relationship with either a man or a woman. Woolf writes that:

What Sally felt was simply this. She had owed Clarissa an enormous amount. They had been friends, not acquaintances, friends, and she still saw Clarissa all in white going about the house with her hands full of flowers - to this day tobacco plants made her think of Burton. But-did Peter understand? - she lacked something. Lacked what was it? She had charm; she had extraordinary charm. But to be frank ... how could Clarissa have done itmarried Richard Dalloway? a sportsman, a man who cared only for dogs. Literally, when he came into the room he smelt of the stables. And then all of this? She waved her hand. ${ }^{41}$

\footnotetext{
${ }^{36}$ Eve Sedgwick, Epistemology of the Closet, (California: University of California Press, 1990), p.1.

37 Helt., p.233.

38 Ibid., p.234.

39 Ibid, p.234.
}

40 Olivia Wood 'A Diamond and a Tropic Gale: Reexamining Bisexuality in Mrs. Dalloway', Journal of Bisexuality, 18 (3), $382-$ 394, p.395 <https://dx.doi.org/10.1080/15299716.2018.1540374> 
Similarly, this issue is still raised on TikTok. For example in a less ironic and more realist tone @kaptain.Kenuckles utilizes a shot-reverse-shot technique of himself, in a medium close-up of a quasi-interview dynamic where he very matter of factly declares this that he feels should be self-evident, but are distorted and obfuscated in mononormative spaces that limit how we perceive bisexuals. He states that 'a bisexual person in a heterosexual relationship does not make them straight [..] vice versa with a gay relationship, this should be obvious but it's not'. The flipside of this is the positive and truly wholesome moments where, usually in a domestic setting amongst familial familiarity (unlike the biphobic public ridiculing of bisexuality such as is seen in the coffee shop in Sex and the City), there is an almost carnivalesque suspension of the gay/straight lines of interrogation that usually inform monosexist assumptions. There are various TikTok's where the user, in real-time, films their coming out to their parents, friends, or queer family and they are truly wholesome to watch. A great example of this utopian transgression from limiting demarcations of the 'chronic now endemic crisis of hetero- and homosexual definition' is user @the_best_disappointment who films their coming out by presenting a cake to their family. When the mother cuts the cake the bisexual colours are visible and her mum accepts it: there are no questions and therefore there is no explanation, it's a very pure 'moment of being ${ }^{42}$.

Both Woolf and TikTok users demonstrate a desire to dismantle problematically reductive black and white thinking that, in Meg-John Barker's thinking in Non-Binary Lives, An Anthology of Intersecting Identities, serves an ideological purpose to regulate power dynamics and oppress the 'other', the 'other occupying a subservient, subjugated and subordinate space and identity ${ }^{\prime 3}$. However, there is a slight difference in that works like Orlando offer a deliberate rejection and resistance to types, labels, and sexological taxonomies of identity, and those bisexual users on TikTok would appear to want to reclaim their uniqueness as types. Consequently, there is a tangible emphasis on language and the naming of the thing. By contrast to the effortless deployment of terms like 'bisexual', 'bi-erasure','biphobia' and exquisitely explained distinctions between gender identity, expression, sexual orientation, and sexual preference (and the active promotion of hashtags such as \#bisexualityisvalid), Woolf carefully removes all but the latter of these constraints for Orlando, so that Orlando's story demonstrates that gender is socially constructed, even performative in the Butlerian sense, and that desire is naturally and commonly polymorphous or bisexual when re-leased from social strictures' 44 the "narrowing and naming" of "these immensely composite and wide-flung passion' (Woolf) 'the trap of sexual taxonomy that Woolf rejected ${ }^{45}$

What is shared though is a desire to turn the Freudian idea of a polymorphous subconscious inside out and to place a polymorphous desire in the centre and nullify the idea propounded in Freud's psycho-analytic research, that, as Freud wrote, 'has found that all human beings are capable of making a homosexual object-choice and have in fact made one in their unconscious. Indeed, libidinal attachments to persons of the same sex play no less a part as factors in normal mental life ... than do similar attachments to the opposite

\footnotetext{
42 Woolf., 1976, p.3.

43 Meg-John Barker, 'Nn-Binary Interesctions and Gender Euphoria', in Non-Binary Lives, An Anthology of Intersecting Identities, ed. by Meg-John Barker, Jos Twist and Kat Gupta (London: Jessica Kingsley Publishers, 2020), pp.233-278 (p.234).

44 Helt., p. 233.

45 Wood, p.399.
} 
sex $^{46}$. In Woolf's work however, bisexual desire seems to be the most common and therefore most easily naturalized experience of adults. Woolf's theories of sexuality foreground the ways social realities such as class systems, financial means, epistemologies of sexuality and gender, and hegemonic power structures determine the possibilities for a given individual of bringing desires to consciousness and pursuing them. These both challenge binary thinking that Cixous explains using a list of binary oppositions such as 'sun/moon that Helt recognizes in sexology's over-reliance on a 'normal/ abnormal' dichotomy, one that cemented its investigatory framework with the Ellisian advance in English sexology ${ }^{47}$. There is usually a preponderance of possibilities that are thought of before bisexuality or pansexuality is arrived at. For many bisexuality is still a temporally transient act, not a lasting identity. As Wood (2008: 34) asserts, 'Clarissa Dalloway is more than just what she does'.

This impulse is demonstrated again when in Mrs Dalloway we hear of "something warm which broke up surfaces and rippled the cold contact of man and woman, or of women together. For THAT she could dimly perceive". This is intended to refract the regulations of Freud's imagining of bisexuality as a subconscious (or really, a pre-conscious) desire, one that is untamed and unregulated, unlike matured monosexuality, precisely by rendering this bisexual desire as part and parcel of what I would call polymorphous reality but what Woolf would describe as 'an ordinary mind on an ordinary day' - Indeed, like those TikTok users that will include songs like Demi 'I like boys I like guys', Woolf's polymorphous reality in Orlando channels Orlando's desire, 'irrespective of gender' such as Orlando's attraction to Sasha whose appeal is relayed by her 'extraordinary seductiveness which emanated from the whole person' (Orlando) 38). Note the use of the gender-neutral language here 'the whole person, and not the personal pronoun 'her'. When he believes her to be a boy, he wants to "tear his hair with vexation" at the thought that he cannot embrace the object of his desire (Helt, 2010 p.17) 'she reaps a twofold harvest and enjoy[s] the love of both sexes equally" (Orlando, 1928). "the love of both sexes" (Orlando, 1928). What is different, however, is that whereas Woolf propagated a politics of 'indifference' and advocated for one to remove oneself from the patriarchy, and all their attendant labels, categories, and 'other' that enunciated strategies for subjugation and control, TikTok users knowingly parody bisexual stereotypes in deliberate pastiche where the stereotypes promoted by monosexist systems of classification and of identity are exhibited in such away that speaks to their self-contradictions and problematic nature. Indeed, where Woolf would ask one to 'begin inwardly' in an insular private world of separation from the external spaces of suppressive mononormativity the TikTok user explicitly exhibits the problems of those monosexist systems that delegitimize bisexuality. For instance, Woolf might ask her readers to retreat' inward' to carve out a new polymorphous possibility of sexuality that can suffuse the conception and gestation of the 'forming [of] new wholes, [where] there will be born a language, which will be music, poetry, \& painting' (Draft Y5 114). Artistry lies in resigning oneself whereas on TikTok resistance to the 'fixity' of the gay/straight binary is through, with deliberate irony, a matter of fact speech act of selfdepreciation as when user @stanzipotenza visualizes their DM's and responds by saying 'I am nothing and everything at the same time. That's right I'm a double agent'. Another commonality is that both Woolf and TikTok users demonstrate a desire to challenge the 'it's just a phase' misconception about bisexuality. Challenging the idea propounded $n$ sexology that bisexaluliaty was an infantile 'state', Woolf knowingly foregreounds and challenges this thinking as when Clarissa thinks, "But it might be only a phase, as Richard

46 Sigmund Freud, Three Essays on the Theory of Sexuality, in The Essentials of Psychoanalysis Sigmund, trans. by James Strachey (London: Vintage Books, 1905; repr. 2005), 277-376.

47 For an extended discussion of both the limitations and the impact of Ellis' sexological investigations see Anna Katharina Schaffner, 'Sexology in England', in Modernism and Perversion Sexual Deviance in Seexology and Literature, 1850-1930 (Hampshire: Palgrave Macmillan, 2012), pp.89-112. 
said, such as all girls go through'. It might be falling in love. But why with Miss Kilman?" (Mrs Dalloway, p. 11 in Wood, p.10). This subverts what is initially set up as an espousal of the sexological view of all girls going through bisexuality as a phase by then doubling back on this to focus on the person, not the gender- 'why Miss Kilman?'- the speaker's surprise is not of same-sex desire but of the choice of a person, not a choice of gender, implying that what is chosen is the person's specificities, not their gender specificity. The spectacle, the 'queer' is the insular categories that things are put into.

Similarly, on TikTok, there is an explanation of how bisexual desire is experienced that in part echoes the Freudian definition of the bisexual object-choice as that which 'combines masculine and feminine attributes', what Freud determined was a reflection of the bisexual self. User @madsteaparty, using an image that rendered visible, like Orlando, both the masculine and feminine elements of a person, explains that being bisexual in a straight/gay world is thinking 'who I should look at, is it Shang or Mulan?' in reference to the male and female protagonists of Disney's 1998 animated feature-film Mulan. There are also commonalities in TikTok's where many users deliberately draw attention to androgynous clothing and make-up with nail polish being a frequent visualization of binaryrupturing aesthetics. Where this observation risks conflating socially constructed modes of gender expression with sexuality, it is mitigated by the fact that these binary-rupturing ways of dressing show that the users are deliberately engaged in strategies that invite the viewer to enter those liminal, in-between states that Virginia Woolf would desire in her fiction as Between the Acts or in her Sketches of the Past memoirs as with her frequent use of the adjectival phrase 'semi-transparent' and her liminal imagery as when she takes note to those 'showing the light through but not giving a clear outline', 'the murmur of bees' as she 'lay there half awake, half asleep, drawing in such ecstasy as I cannot describe' ${ }^{48}$ that framed and fuelled her epiphanic moments of being 'ecstatic', removed from moulds and monolithic modes of identity. This ecstasy of the in-between is a space that is still being carved out online on TikTok.

\section{Heterotopic limitations}

With all this in mind, it is arguable that bisexuality, or that is, the ability to express bisexuality is still limited because of how bisexuality functions as a subjective form of Michel Foucault's 'heterotopia'. Foucault describes, in spatial terms, his mapping out of the heterotopia as: Its heterotopic presence can be felt online wherein images 'simultaneously represents, contests and inverts' both opposite and same-sex desire, 'exist[ing] outside of all [mononormative] places'. Bisexual representation also exists as a heterotopia within the institutions that inform our representations of, and in turn determine how we write and project our bisexual selves, bodies, and thoughts online and in print. Bisexuality is relegated to the realm of 'fantasy' that 'exists outside of all places' such as the instances of clinical practice that Esther Rapport identified in 2012. Rapport referred to the classical analyst Joyce McDougall who held the conviction that monosexuality was a mode of maturation and that it was an inevitable part of reality. McDougall stressed the 'necessity to accept our inescapable monosexuality'. If bisexuality was to be imagined, within the paradigm of sexual development scaffolded by McDougall, it was only to be 'in dreams [where] we are all magic, bisexual and omnipotent'. ${ }^{49}$ Perhaps because of the resonance of heterotopic bisexuality from Woolf's time to now, there is still the issue outlined by Ault (1999) who noted that 'despite bi women's conscious objections to the binary structures of sex, gender, and sexuality, their discourse on sexual subjectivity is inescapably

\footnotetext{
48 Woolf, 1938, p.112.

49 McDougall, J. (1986). 'Eve's reflection: On the homosexual components of female sexuality', in Between analyst and patient: Dimensions in countertransference and transference, ed. by H. Meyers (Ed.), (pp. 213-228) (Hillsdale, NJ: Analytic Press, 1986)
} 213-228, (p.222). 
marked by these discourses' (p. 173). Nowhere is this heterotopic limit of bisexual representability more evident than in the construction and consumption of images on the social media platform Instagram, specifically those images tagged with the hashtag \#biguys and/or \#biboys.

\section{Conclusion}

This comparison between TikTok and Woolf has sought to tease out both commonalities and differences and the continued limitations of bisexual representation. It is clear that bisexuality still needs to be explained, evidenced and visualized (through Orlando's androgyny and/or TikTok users offering a commentary on an attraction to both male and female characters in films such as Mulan. It is also clear that strategies of resistance to mononormative and monosexist ideologies are difficult to transcendence and therefore deconstruct because hashtags and modernist techniques are both forced to say gay/straight to discuss bisexuality. It is difficult to describe a bisexual whole when both parts are too-often read as wholly themselves. It is very telling as well that TikTok users seek to challenge binary thinking in 2021 and in order to progress we need to examine how and why representing bisexuality is difficult in a world of binaries where, as philosopher Jacques Derrida reminds us is what Western thinking rests on as he draws attention to the perpetually absent ghostly referent that persistently lurks in the background rendering 'absence' as 'the lack of presence, 'evil' as the fall from good error as a distortion of truth' and same-sex desire as the absence of heterosexuality ${ }^{50}$ In both Woolf's literary aesthetics and the videos uploaded to TikTok, it is clear that bisexuality needs an aesthetic model that can offer a holistic mirror to the multiplicities of bisexual desire. We need to Conflicts of Interest: The authors declare no conflict of interest." tell our own stories, the gender of our partner are not our narrators.

\section{References}

Angelides, Steven A History of Bisexuality (London: University of Chicago Press, 2001).

Bailey, H, Bower, J and Gurevich, M (2012) Querying Theory and Politics: The epistemic (Dis)location of Bisexuality within Queer Theory. In: Alexander, J and Anderlini-D’Onofrio, S (eds.) Bisexuality and Queer Theory. London: Routledge. pp. 43-65.

Barker, Meg-John. 'Non-Binary Intersections and Gender Euphoria'. In Non-Binary Lives An Anthology of Intersecting Identities, edited by Jos Twist, Ben Vincent, Meg-John Barker and Kat Gupta, 159-166. London: Jessica Kingsley Publishers, 2020.

Bland, Lucy and Doan, Laura Doan. Sexology Uncensored The Documents of Sexual Science. Cambridge: Polity Press, 1998.

Boone, J. Libidinal Currents Sexuality and the Shaping of Modernism (Chicago and London: University of Chicago Press, 1998)

\footnotetext{
${ }^{50}$ Gibian, Ruth (1992) 'Refusing Certainty: Toward a Bisexuality of Wholeness', in (ed. Weise, Elizabeth Reba) Bisexuality and Feminism, Seattle: The Seal Press, pp.3-16
} 
Brandon Rogers (2020) \#Biguys and \#Biboys: The Discursive Production of Bisexual Men through Instagram's Homonormative Visual Culture, Journal of Bisexuality, 20:4, 361-382, DOI: $10.1080 / 15299716.2020 .1823298$

Butler, Judith (1990) Gender Trouble: Feminism and the Subversion of Identity. (New York: Routledge, 1990)

Butler, Judith. Bodies that matter: On the discursive limits of “sex”. (London: Routledge, 1994)

Cixious, Helene 'Sorties: Out and Out: Attacks/Ways Out/Forays', in (eds. Belsey, C and Moore, J) (1989) The Feminist Reader: Essays in Gender and the Politics of Literary Criticism, New York: Basil Blackwell, pp.101-116.

Havelock Ellis 'Studies in the Psychology of Sex, vol.II: Sexual Inversion', in Sexology Uncensored The Documents of Sexual Science, ed. by Lucy Bland and Laura Doan, Cambridge: Polity Press, 1998), pp.52-57

Cramer, Patricia 'Virginia Woolf and Theories of Sexuality', in The Cambridge Companion to Virginia Woolf, Cambridge: Cambridge University Press, 2003).

Ellis, H 1910 Studies in the Psychology of Sex, vol. I: The Evolution of Modesty, The Phenomena of Sexual Periodicity, Auto-Eroticism. In: Bland, L and Doan, L (eds.) (1998) Sexology Uncensored: The Documents of Sexual Science. Cambridge: Polity Press. pp. 244-246.

Freud, Sigmund, Three Essays on the Theory of Sexuality, in The Essentials of Psychoanalysis Sigmund, trans. by James Strachey (London: Vintage Books, 1905; repr. 2005), 277-376.

Foucault, Michel, A History of Sexuality, (New York: Pantheon Books, 1978)

Foucault, Michel, of Other Spaces: Utopias and Heterotopias. 1967. Available at: $<$ https://web.mit.edu/allanmc/www/foucault1.pdf >

Garber, M 1995 Vice Versa: Bisexuality and the Eroticism of Everyday Life. (London: Routledge, 1994)

Gibian, Ruth 'Refusing Certainty: Toward a Bisexuality of Wholeness', in Bisexuality and Feminism, ed. Weise, Elizabeth Reba (Seattle: The Seal Press, 1992), pp.3-16.

Helt, Brenda S. 'Passionate Debates on "Odious Subjects": Bisexuality and Woolf's Opposition to Theories of Androgyny and Sexual Identity', Twentieth Century Literature 56, no. 2 (2010), 13167. <http://www.jstor.org/stable/41062468>

James, Christopher 'Denying complexity: The dismissal and appropriation of bisexuality in queer, lesbian, and gay theory' in Queer Studies: A Lesbian, Gay, Bisexual, and Transgender Anthology ed. by Brett Beemyn and Michelle Eliason, (New York: New York University Press, 1996), 321-335 (p.322). 
McDougall, J. 'Eve's reflection: On the homosexual components of female sexuality', in Between analyst and patient: Dimensions in countertransference and transference, ed. by H. Meyers (Ed.), (pp. 213-228) (Hillsdale, NJ: Analytic Press, 1986) 213-228, (p.222).

Margaret Mead, Coming of Age in Samoa (1928; London: Pelican Books, 1975); Margaret Mead, "Bisexuality: What's it All About?," Redbook, January 1975, 29-31.

Moddelmog, D. 'Modernism and Sexology', Literature Compass 11, no.4 (2014) pp. 267278. < <ttps://doi.org/10.1111/lic3.12140> pp. 267-278.

Ken Plummer, Telling Sexual Stories . Power, Change and Social Worlds. (London: Routledge, 1995)

Power, Arthur Conversations with James Joyce, (The Lilliput Press: London, 1974/99).

Rapoport, E. (2012). Bisexuality in psychoanalytic theory: Interpreting the resistance. In Alexander, J. \&Anderlini-D’Onofrio, S (Eds.), Bisexuality and queer theory (pp. 87-104). Routledge.

Rueclous, (13 Dec, 2020) 'bisexual tiktoks (mostly wlw) for when you don't exist', Youtube, Available at: https://www.youtube.com/watch?v=K91coVGCe7I [Accessed 23/12/2020].

Said, Edward Orientalism (London: Routledge and Kegan Paul, 1978). .

Schaffner, Anna Katharina, Modernism and Perversion Sexual Deviance in Sexology and Literature, 18501930, (Hampshire: Palgrave Macmillan, 2012), pp.89-112.

Sedgwick, E. K. (1985). Between men English literature and male homosocial desire. University of California Press.

Sedgwick, Eve Epistemology of the Closet, (California: University of California Press, 1990), p.1.

Storr, M. (1999). Bisexuality: A critical reader. Routledge. Storr, M. (1999). Transformations: Subjects, categories and cures in Krafft-Ebing's sexology. In L. Bland \& L. Laura Doan (Eds.), Sexology in culture labelling bodies and desires (pp. 13-33). Polity Press

Storr, M 1998 Transformations: Subjects, Categories and Cures in Krafft-Ebing's Sexology. In: Bland, L and Doan, L (eds.) Sexology in Culture: Labeling Bodies and Desires. Cambridge: Polity Press. pp. 11-26.

Tran, Ben 'Queer Internationalism and Modern Vietnamese Aesthetics', in The Oxford Handbook of Global Modernisms, ed. by Mark Wollaeger and Matt Eatough (Oxford: Oxford University Press, 2019), pp.367-384. Wood, Olivia (2018) A Diamond and a Tropic Gale: Reexamining Bisexuality in Mrs. Dalloway, Journal of Bisexuality, 18:3, 382-394, DOI: $10.1080 / 15299716.2018 .1540374$

Woolf, Virginia,The Diary of Virginia Woolf Ed. Anne Olivier Bell. Vol. 3. New York: Harcourt, 1980. 
Woolf, Virginia, 'A Sketch of the Past'in Moments of Beinged. JeaneSchullkind $2^{\text {nd }}$ ed. San Diego: Harcourt, 1985.

Woolf, Virginia 'Old Bloombsury',in Moments of Being ed. JeaneSchullkind $2^{\text {nd }}$ ed. San Diego: Harcourt, 1985.

Woolf, Virginia(1925),Mrs Dalloway, New York: Harcourt, 1953.

Woolf, V 1929 A Room of One's Own. London: Hogarth Press.

Woolf, Virginia(1928), Orlando: A Biography, San Diego: Harcourt, 1957.

Woolf, Virginia. 'Modern Fiction', in The Essays of Virginia Woolf Volume 4: 1925 to 1928, ed. by Andrew McNeille (London: The Hogarth Press, 1984), pp.157-164.

Woolf, Virginia Orlando , (London: Penguin, (1928) 2005)

Woolf, Virginia 'Old Bloombsury',in Moments of Being ed. Jeane Schullkind $2^{\text {nd }}$ ed. (San Diego: Harcourt, 1985), p.43. 